\title{
Ongoing University Teachers and the Complexity of Their Knowledge Dynamics
}

\author{
Pricila Kohls dos Santos ${ }^{1}$, Marilia Costa Morosini ${ }^{1}$, Claus Dieter Stobaus ${ }^{2}$ \\ ${ }^{1}$ Postgraduate Programs in Education, Pontifical Catholic University of Rio Grande do Sul, Porto Alegre, Brazil \\ ${ }^{2}$ Postgraduate Programs in Education and in Biomedical Gerontology, Pontifical Catholic University of \\ Rio Grande do Sul, Porto Alegre, Brazil \\ Email: stobaus@pucrs.br
}

How to cite this paper: dos Santos, P. K., Morosini, M. C., \& Stobaus, C. D. (2017). Ongoing University Teachers and the Complexity of Their Knowledge Dynamics. Creative Education, 8, 1069-1087.

https://doi.org/10.4236/ce.2017.87077

Received: May 8, 2017

Accepted: June 6, 2017

Published: June 9, 2017

Copyright $\odot 2017$ by authors and Scientific Research Publishing Inc. This work is licensed under the Creative Commons Attribution International License (CC BY 4.0).

http://creativecommons.org/licenses/by/4.0/

\begin{abstract}
The article aims to analyze the dynamics of teacher knowledge construction in a university in Brazil. In order to meet the proposed objective, national policies and institutional policies of teacher education are considered. After the description of the Dimensions of the Dynamics of Teaching Knowledge, Brazilian National Teacher Education Policies, we describe the analysis of studies in the field collected of last five years' thesis and dissertations, and the results of textual analysis of narratives from teachers who participate in MES-Higher Education Methodology Courses at PUCRS.
\end{abstract}

\section{Keywords}

Teachers Education, Higher Education, Brazilian National Education, Complexity of Knowledge

\section{Introduction}

The great expansion of higher education in this century has been a constant preoccupation with the quality of the higher education system. Nations which previously did not have higher education as an important factor in relation to other educational levels began to focus their studies on the formation of high level of human resources for the knowledge society.

This is the case of Brazil, the largest country in Latin America, and is classified as an emerging Great South country. In 2013, the population is $202,768,562$ inhabitants. The higher education in the country is recent. The first high level institution dated 1808. Since this time, the country had a great expansion in higher education system, recently due national policies and the influence of the named knowledge society. 
According Brazilian data (Brasil, 2015), in 2014 there were 2368 high education institutions (-IES) and 7,828,013 students. Despite this expansion, today the gross high education ratio is $27.8 \%$ and the net $\mathrm{HE}$ ratio is $14.6 \%$. The faculties are around 383,386 , with $35.1 \%$ having a doctorate degree, $39.3 \%$ master's degree, $23.1 \%$ specialization and $2.1 \%$ other educational levels.

In the search for a better quality for higher education, focusing on faculties, highlights the importance of considering the dynamics of knowledge, as says Eisner (2017). This is impacted by the interaction between research and practice that shape teacher knowledge.

Such a position does not imply giving up traditional teacher education, with guidelines focused on methods and techniques, but this is increased by the knowledge of available tools and resources, as well as an analysis with an investigative and innovative look.

Because of this dynamics, applications can be identified in teaching practice, making it possible to raise awareness of what is really known, what is not known and what needs to be known. In this way, the teacher is able to combine the content worked with his students to the daily life of these students, creating and recreating a rich environment of production of knowledge in which all are both authors and learners (Gale, Mills, \& Cross, 2017).

So, it is necessary to constitute an environment of joint construction of knowledge, according Kolb, \& Kolb (2005), even, and mainly, in teacher education courses.

Teachers education is a widely discussed and widespread concept in academia, and this is a real need not only for the University but also for the whole field of Education. The University has the role of preparing professionals to work in schools and educational institutions and system, but this role does not belong to it alone.

Zabalza (2015) emphasizes that teachers education is a permanent process of searching for knowledge, innovation and qualification of the practice, with the responsibility of each professional for their qualification and update/expansion of their knowledge. In this sense, they are 'educational needs' to be planned for the whole period of professional life, also being the University's role provide this conditions, so that students can continue this supported education on their own.

Thus, education is an ongoing process that is developed along the personal and professional trajectory, and can be translated, says Nóvoa (1997: p. 26) as "exchange of experiences and sharing of knowledge consolidate spaces of mutual formation, in which each teacher is called to simultaneously perform the Role of trainer and trainee".

To do it, one of its presuppositions is keep in mind that this environment ha human beings with different experiences and life histories and formation. This, in turn, can further enrich this quest for their knowledge, abilities and attitudes.

It is noteworthy that there is a common sense regarding the teaching work and its position in our society of the learning, proclaimed Aretio, Corbella, \& Figaredo (2007), where it is expected that every teacher is researcher and is sys- 
tematically placed in the condition of lifelong apprentice, an unfinished being and constantly updated.

The insertion of complex thinking into educational programs allows a dialogue between scientific and everyday knowledge and the reconfiguration of knowledge in a more universal study focused on practical and contextualized questions, says Morin (2014).

To that end, the need arises for understanding evidences and produces new potentialities and abilities to the traditional teaching competencies, so that the formal education offered in the school can approach in the knowledge society like increasingly critical, creative and inquiring needs, but also with research habits, ethical posture and attitudes committed to the sustainability of life on this planet.

In this sense, it is not possible to deal with teacher education that is far from the idea of universalizing knowledge, because the education process is complex and involves more than just scientific knowledge, because also involves the trajectory and historicity of each individual, in his/her particular culture.

Since for Morin (2007), complexity also includes uncertainty, indeterminations, random phenomena.

In this sense, Snyder (2013: pp. 28-29) points out that the education system is complex and, therefore, teacher training is also, so the theory of complexity is helping to rethink the construction of knowledge and teaching practice. In this sense, the author presents some actions to operationalize a complex approach in the educational system, which are:

1. Fostering a collaborative environment throughout the system by actively creating opportunities for interaction [...]

2. Designing ways for collaboration and interaction to be continuous [...]

3. Making reforms iterative, experimental and flexible [...]

4. Adapting a "non-deficit" approach to reform [...]

5. Focusing on a few key nodes and pursuing them collaboratively [...]

6. Engaging and energizing teachers through collaborative research and longer term peer-to-peer mentoring [...]

7. Taking on board the developments and management structures of other sectors and industries.

Complementing this thinking process management of Dimensions of the Dynamics of Teaching Knowledge (Table 1), it is fundamental, for Guerriero (2017), that contains aspects as involving connectivity, co-evolution, emergent order, cascade effect, diversity and internal redundancy, decentralized peer interactions and control. These factors allow the understanding of the dynamics of teacher knowledge and of the continuous (re)organizational form, to facilitate the integration and sharing of new teacher knowledge.

\section{Brazilian National Teacher Education Policies}

In Brazil there are national policies aimed at qualifying teachers who work from basic education to higher education. However, there is no specificity in the leg- 
Table 1. Dimensions of the dynamics of teaching knowledge.

\begin{tabular}{|c|c|}
\hline Dimensions & Conceit \\
\hline Connectivity & $\begin{array}{l}\text { The inter-connectedness and inter-relationship between multiple agents } \\
\text { of the system, and between these agents and their environment. } \\
\text { In the case of knowledge dynamics the agents can be the actors of the } \\
\text { education system: researchers, teachers, school leaders, policy-makers, } \\
\text { students, parents, etc. or e.g. the different groups of local actors: } \\
\text { the teaching staff at a school, the members of a school board and so on. }\end{array}$ \\
\hline Co-evolution & $\begin{array}{l}\text { Elements of the system change based on interactions between them. } \\
\text { The interactions provide feedback on themselves } \\
\text { (and on the relationships and actions) after a number of steps, and } \\
\text { these feedback loops are the drivers for the evolution of the system. }\end{array}$ \\
\hline $\begin{array}{l}\text { Emergent } \\
\text { order }\end{array}$ & $\begin{array}{l}\text { Interactions of the agents result in some kind of global property or } \\
\text { pattern that could not be predicted by any individual agent's actions } \\
\text { or interactions. Thus, unpredictable behaviors and patterns arise. }\end{array}$ \\
\hline $\begin{array}{l}\text { Cascading } \\
\text { effects }\end{array}$ & $\begin{array}{l}\text { Interactions are non-linear, and even small changes in inputs, } \\
\text { interactions, or stimuli can cause very significant changes across the system. }\end{array}$ \\
\hline $\begin{array}{l}\text { Internal } \\
\text { diversity }\end{array}$ & $\begin{array}{l}\text { Diversity of the elements or agents is an important source of "intelligent" } \\
\text { responses to emergent circumstances. Professional communities, at any level } \\
\text { represent a large diversity of professional and educational backgrounds, } \\
\text { interests and experiences, and thus can better react to the changing environment. }\end{array}$ \\
\hline $\begin{array}{l}\text { Neighbor } \\
\text { interactions }\end{array}$ & $\begin{array}{l}\text { Neighbors in this context are interpreted as ideas, views, etc., that must be } \\
\text { able to interact. It is thus not necessarily enough that researchers and } \\
\text { teachers meet and talk, what matters is that there is space and opportunity } \\
\text { for them to compare, contrast, collide, or juxtapose their ideas. }\end{array}$ \\
\hline $\begin{array}{l}\text { Decentralized } \\
\text { control }\end{array}$ & $\begin{array}{l}\text { In order to enable neighbor interactions the control of the structure } \\
\text { and outcomes of a knowledge-producing collective } \\
\text { must be decentralized, that is, arising in local activities. }\end{array}$ \\
\hline
\end{tabular}

Source: adapted from Guerriero (2017).

islation on how and what should be the formation of the teacher of higher education. According to Law No. 9394 named LDB-National Guidelines and Bases Law (Brasil, 1996), university teachers should have technical competences, understood as a domain of the area of knowledge, and for universities there are required that at least one third of the faculty must have a master/doctorate degree. That is, although the current legislation does not determine that the acting teachers need specific training for teaching, in addition to the technical knowledge of each area.

So, some initiatives have been offered by the Brazilian government in this direction in the last decades that aims to provide future teachers with participation in methodological, technological and teaching practices. There have innovative and interdisciplinary nature, that seek to overcome teaching and learning processes (and some of their problems solution): Initial and Continuing Program, Presential and Distance, for Teachers of Basic Education (named PARFOR); Institutional Program for the Initiation to Teaching (PIBID) for the basic education.

The Baccalaureate Consolidation Program (named Prodocência) offers financial support to institutional projects that contribute to innovate teacher educa- 
tion courses. Another initiative is the UAB Diversity Education Network, for the initial and continuing training of Basic Education professionals, through distance methodology for insertion of diversity themes in the Basic Education networks in Brazil.

The Teacher Portal (named Portal do Professor) is a technological solution that allows the storage and circulation of multimedia educational content, offering educational support, especially for teachers working in Basic Education.

As governmental initiatives for training in Higher Education, the Institutional Program for Teacher Qualification for the Federal Network of Professional, Scientific and Technological Education (named PIQDTEC) foment the qualification in masters and doctorates degrees, and there is a Program of Concession and Maintenance of Scholarships Graduate in the Country.

Thus, although such initiatives do not refer specifically to teaching in Higher Education, these are important instruments in the attempt to qualify Brazilian education. In this sense, taking into consideration that, although the requirement for universities falls on the postgraduate training of its faculty, it implies on university teaching, since every Institution of Higher Education (HEI) is submitted to evaluation through the National System (SINAES), from the perspective of institutions, courses and student performance.

This evaluation process takes into account aspects such as teaching, research, extension, social responsibility and insertion, and management of the institution and faculty. Thus, aiming at the qualification of the offered education courses, in general institutions also offer continuing education courses to their teachers, one of which is a course that involves education for university teaching.

As synthesis thinking, it can identify that although national policies do not have university teachers as their direct focus, SINAES indirectly performs the evaluation of the national system and the evaluation of the teacher, and is considered as defining the quality of the Course. This implies that Higher Education institutions (must) implement programs, courses, and other forms of training to qualify their teachers.

\section{Brazilian Researches in Teacher Education}

Brazilian national policies and actions for teacher education show a plurality and dynamicity. In this sense, we present now some institutional programs of teacher education selected from Dissertations and Thesis, produced in Brazil and registered in the Brazilian Digital Library of Theses and Dissertations (http://bdtd.ibict.br/vufind/), in the last five years. The keywords used in the search engine were: 1) Teacher Education in Higher Education (332 results); 2) Institutional Education Programs (114 results); 3) Continuing Education of Teachers in Higher Education (329 results).

It is worth mentioning that a large part of this scientific production focuses on the continuing education of Basic Education teachers, as well as on teacher professionalism and their constant updating.

From the perspective of teacher education for Higher Education, it has also 
appears that this topic is usually discussed and worked with beginner teachers or, also, with teachers joining the isolated High Education institutions, in other words, newly hired. The institutions take advantage of this space to share the philosophy of work adopted, which would not specifically meet the premise of teacher education in a broader sense, that is, the inherent complexity of the everyday classroom in higher education.

Thus, due to the complexity of the topic, the presented results were submitted to a new filter using the correspondence of the terms teacher education and institutional programs, both focused on Higher Education. This refinement resulted in the selection of 14 papers (Table 2), of which 6 Master Dissertations and 8 doctoral Thesis. Of the institutions surveyed, 10 are public (free) and 4 private (paid) institutions, only 3 integrate a core and/or Department for Teacher Education, 2 of which are Postgraduate, 2 Institutional Projects and 7 refer to Courses offered by the institutions to its faculty.

It is observed that Thesis and Dissertations data seem to suggest that Brazilian universities invest in the qualification of their teaching staff, allocating material and personnel resources for teacher training actions.

In this respect, we highlight some actions present in the analyzed studies: 1) Workshops/Meetings of professionalization; 2) Training cycles for teaching in higher education; 3) Post-Graduation Lato Sensu in Teaching in Higher Education; 4) Projects focused on the construction of the teaching identity and a culture more focused on research; 5) Pedagogical Education: Teaching, Learning and Assessment in Higher Education; 6) Active Methodologies and New Technologies; 7) Education Improvement Programs; 8) Pedagogical Education and Institutional Culture; 9) Post-Graduation Strictu Sensu; 10) Continued Pedagogical Training Program for Teaching; 11) Department-Area of Support to Teaching and Learning. The consulted researches are from Maraschin (2012); Torres (2014); Garcia (2012); Araújo (2014); Alves (2013); Conte (2013); Santos (2013); Selbach (2015); Debald (2014); Moreira (2014); Sousa (2013); Vilela (2016); Couto (2013); and Ramos (2014).

In order to exemplify some of the aforementioned actions, we present the research entitled "Continuing education of the teacher of higher education promoted by institutional actions" (Maraschin, 2012), carried out in a community private institution, through interviews with teachers, about Institutional actions of continuing education. The author points out that, in general, teacher edu-

Table 2. Teachers education initiatives Brazil, 2011-2015.

\begin{tabular}{cccccc}
\hline & \multicolumn{5}{c}{ Teachers Education initiatives } \\
\cline { 2 - 6 } & & Departments & Projects & Short Time Courses & Postgraduate courses \\
\hline Public institution & 10 & 3 & 1 & 5 & 1 \\
Private institution & 4 & - & 1 & 2 & 1 \\
Total & 14 & 3 & 2 & 7 & 2 \\
\hline
\end{tabular}

Source: the authors. 
cation actions fall on the beginning teacher and/or the teacher who joins the institution, but also stresses that these actions are surrounded by resistances and formats that are not attractive.

In the institutions researched at this study, three specific actions are offered, held at the beginning of each semester: Workshops/Professional Meetingswhich involve questions about the institution itself, planning, evaluation, interpersonal relations, and other typical College Education.

The education cycles for teaching in Higher Education-systematic activity that includes aspects of teaching, research and extension, as well as methodological modalities, in tune with the specificities of the areas and the content of the courses themselves. And the Lato Sensu Postgraduate in: Teaching in Higher Education-which is part of the institutional efforts to qualify the university class forming pedagogical articulations for undergraduate courses.

These actions, as explained by Maraschin (2012), are strengthened based on the results of the institutional evaluation carried out every six months with the IES students. They seek to meet general and specific demands to produce individual and collective changes stemming from concerns experienced by students, teachers and managers of the institution.

Another initiative regarding teacher education is presented by Torres (2014) in his doctoral Thesis titled 'University pedagogy and its relations with institutional policies for the education of higher education teachers', in which analyzed the initiatives of two public universities in the region southeastern Brazil. This research analyzes the offer of training programs of these universities for their teachers, as well as the structure and organization of these. In the first university there is a Continued Pedagogical Training Program for Teaching (named FORPED), consisting of a course and doctoral program, the course being offered two times a year, lasting 8 hours each, and the doctorate lasts 4 years.

The program aims to promote the permanent pedagogical improvement of the teacher, to qualify the teacher in doctoral programs, so that he/she can develop researches. The topics covered are addressed to Pedagogical Practices and New Technologies, with the participation of teachers by means of invitations and convocation, being the teacher's responsibility to attend at least one meeting per year, with the meetings being diversified between Workshops, lectures, seminars, courses, mini-courses among others, having the main focus on teaching undergraduate teaching.

For the Postgraduate Course, there is participation in doctoral programs of other institutions recognized by Brazilian Capes Program and in the Institution itself, such training aims to encourage research by the faculty. From the evaluation of this initiative, and Torres (2014) affirms that it is important to point out that the institution has indicated an increase in the interest of teachers in pedagogical practice and the use of new technologies in the classroom and, as regards To post-graduate, the IES was verified the quality in teaching and research.

The second IES studied by Torres (2014) presents data about Department of Support for Teaching and Learning, responsible for the qualification and im- 
provement of teaching at the undergraduate level, since the institution has a tradition in postgraduate research, in which there are offered workshops, lasting from 2 to 4 hours each, and the topics covered are: Technology and teaching, Didactics/Education/Assessment; Active Methodologies; and Multi/Inter Disciplinary Dialogues.

The participation of teachers occurs through spontaneous demand, or demand detected by the general coordination and coordinators of undergraduate course from the data of the teaching evaluation. A positive result is the increase in the involvement of teachers with undergraduate education, and the diffusion and use of tools that have become frequent in undergraduate classes. Although there are concrete actions in both institutions, the author stresses that the relationship between teacher education and professional development is not yet a concrete reality, since the institutions have their programs focused on institutional needs and do not contemplate the phases of the teaching career.

In summary, these institutional programs of teacher education in Brazil have a variety of forms. Analyzing them from the perspective of the knowledge dynamics proposed by Guerriero (2017), we can see the trend of insertion of these programs into the dimension of internal diversity. At the same time, the studies demonstrate a movement towards the dimension of the emergent order. The courses offered for teacher education are marked by a dimension of the directive order, possibly due to the strength of national policies in the definition of Higher Education in Brazil, and reflected the "pressure" of the evaluation system on Brazilian Higher Education Institutions.

\section{The Experience of PUCRS MES-Methodology of Higher Education Course}

The above review of the main processes that characterize the teacher's knowledge dynamics has shown that multiple factors and actors shape and influence teacher knowledge. In this sense, following the example of Guerriero (2017), in an OECD publication, we use some elements of complexity theory to analyze the dynamics of knowledge established in a group of teacher-students undergoing continuous training. For this, we analyze answers of participant teachers on course of Methodology of Higher Education, proposed at Postgraduate Programs in Education at Pontifical Catholic University of Rio Grande do SulPUCRS, a Community University. The analysis was based on documents such as the course proposal, objectives, activities developed by the teachers in training and the evaluation carried out at the end of the course. The documentary analysis was complemented by the speeches of the students of the course.

In addition to this scope, we emphasize the importance of the ethical questioning of the research, which suggests the care with the collected data, from the confidentiality in the treatment and analysis of the information, as well as the respect the contributions made by the subjects participating in the research. Put ethical procedures in place.

In addition to this scope, we emphasize the importance of ethics in research, 
which suggests the care with collection and collected data, specially about confidentiality in the treatment and analysis of the information, as well as the respect the contributions made by the subjects participating in the research. All subjects were agree with this.

Thus, the collected data were analyzed through the Discursive Textual Analysis technique (Moraes \& Galiazzi, 2007), which proposes the deconstruction, fragmentation and reconstruction of the texts in order to help establish a comprehensive understanding of the data analyzed. We explore the different possibilities that the theory of complexity can offer to seek understanding about the dynamics of knowledge and the consequences that this analytical perspective can have on teachers' knowledge. In this sense, the eight dimensions (Guerriero, 2017), namely connectivity, co-evolution, emergent order, cascade effect, diversity and internal redundancy, interactions with decentralized pairs and control were analytical parameters.

The analyzed course, entitled Higher Education Methodology (MES), held at PUCRS, a private Community University in South of Brazil. It is offered bimonthly to master and doctoral students who seek training for higher education, as well as for teachers who enter the institution and need to participate in the course, in a mandatory, if they do not have previous training specific to teaching.

There is an average participation of 250 student-teachers each year, in groups of 25 participants each, totaling 10 groups, with classes lasting one semester, that is, approximately five months. The course is taught by professors from the entire university (PUCRS) and is imparted at Post-Graduate Program in Education. So, the "population" was these 245 "students" o year 2016 (in reality they are teachers at PUCRS and post-graduate students), and we used (intentionally) some "speeches", considered as important to construct our text.

There are guidelines, objectives and guidelines common to all groups, but each group can have a specific approach according to the participants' area of knowledge. That is, the way is traced in a differentiated way, but with objectives in common to all participants, to provide: critical reflection on the meaning of Higher Education; Fundamentals of educational action and its repercussions on the definition of teaching and learning; Analysis of the educational character of the teaching and the commitment of the teacher with the explanation of a pedagogical proposal mediated by the study and operationalized by different technical procedures of organization the teaching. With these objectives, a critical, emancipatory and humanizing pedagogical practice is sought.

The structure of the course is divided into three dimensions: Political, social and cultural Context of Higher Education; Theoretical-epistemological assumptions and their implications in pedagogical practice; Organization of teaching, with a view to experimenting with different pedagogical practices (Figure 1).

These dimensions involve both theoretical and practical assumptions and are based on the conception of holistic education and inserted in the perspective of intercalated levels: global/regional/national/institutional/local; Theoretical Basis for teacher education and practical experience. 


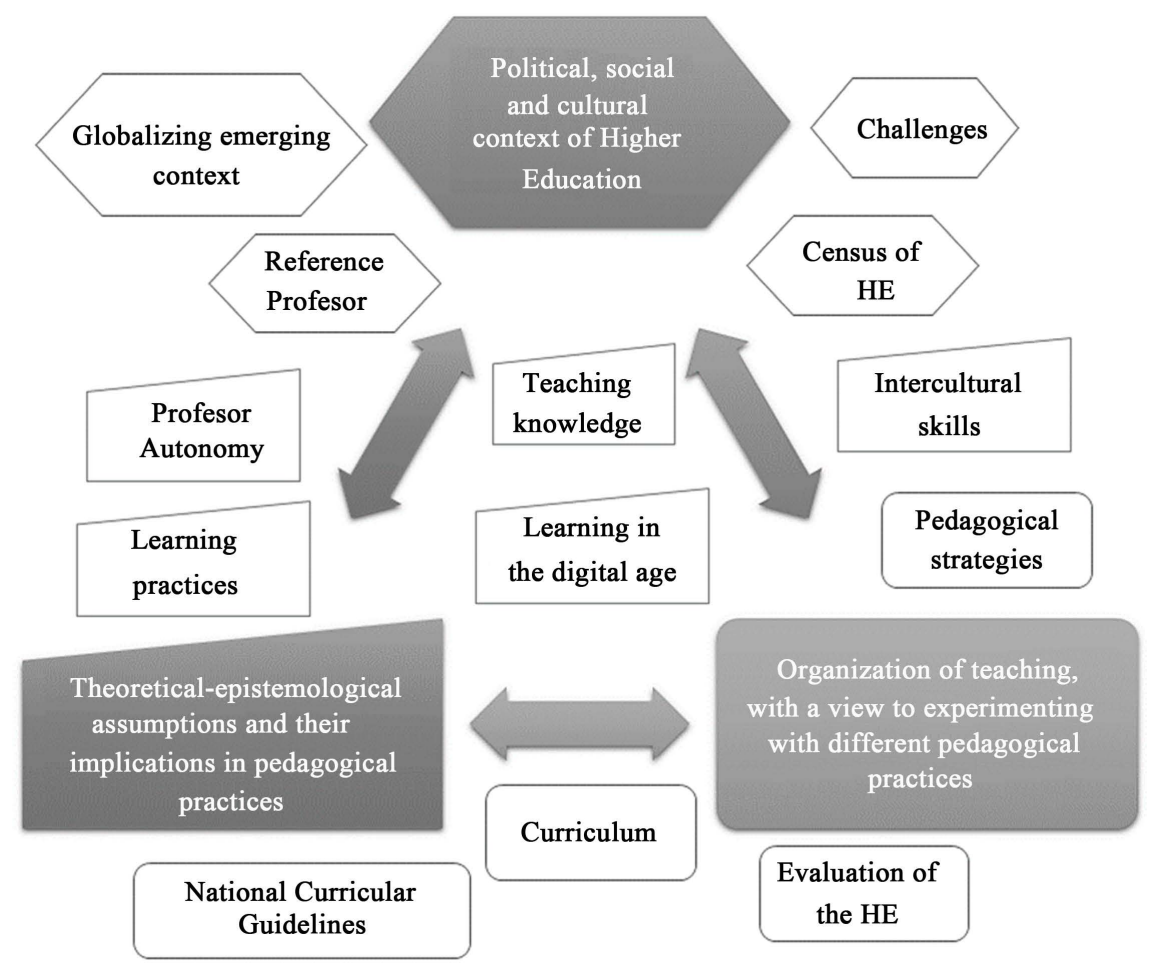

Figure 1. Methodology of higher education course cycle. Source: the authors.

The cycle of the course is composed of the mentioned dimensions and crosscutting themes, so the context dimension is approached taking into account the globalized emerging context, the Brazilian reality of higher education based on census data and the historical perspective, the inherent challenges of Make teacher and by observation activity of the teacher reference.

The theoretical-epistemological dimension discusses teacher knowledge, teacher autonomy, intercultural competences, learning in the digital age and learning practices. Being in the dimension Organization of the education moment in which the educational practices are approached having as bias the $\mathrm{Na}$ tional Curricular Guidelines, the curriculum and the evaluation of the superior education.

Experimental activities analyzed are analyzed two activities carried out along the course that illustrate the Cycle of the Methodology of Higher Education presented here. This study continued the focus on Brazilian higher education and reflected, in addition to studies discussed in the MES course, the positioning of students in the first semester of 2016.

One of the activities developed at the beginning of the course is the Observation of a reference teacher, that is, the observation of a class in higher education, based on a pre-established script, for later presentation and discussion with the other colleagues. The script presupposes aspects related to lesson planning, the teacher's relationship with the students, the methodological procedures and the resources used by the teacher. Such activity stems from the evaluation character or judgments regarding the quality of the class, since it aims at an exempt look at the characteristics that must be present in the university classroom. 
This activity is supported by Kolb \& Kolb (2005) in the principles for the improvement of experiential learning in higher education and suggests that experimental learning can be applied throughout the educational environment through institutional development programs, including the longitudinal evaluation of the results, Curriculum development, student development, and faculty development.

Participant 1 points out in his observation that "greater use of audiovisual resources available in the classroom could serve as an aid to contextualize the subject matter in class, as well as to captivate and instigate students' attention (such as those resources used By lecturers: exhibition of daily news, videos and scenes of films related to the matter addressed, etc.)".

Participant 2 reports on the importance of the activity as an exercise for his role as a teacher in affirming that the observation of the lesson of a reference teacher "allowed me to reflect on my professional practice as a psychopedagogue and made me glimpse with a near future as a teacher of Higher Education".

Concluding the analysis of the national and institutional context, an activity was carried out in which the methodological strategy of Collaborative Writing was used, characterized by the elaboration of a shared real-time essay on the relationship between the National Curricular Guidelines (named DCNs), competencies and course curriculum. For this essay, the areas of knowledge in which the participants act and/or are linked were kept, so the students were organized into groups for discussion and analysis of the proposal and later to register using the Google Docs tool (https://docs.google.com/).

This exercise took into consideration the following questions: 1) How and/or in what item do the competences of the DCNs are present/contemplated in the curriculum of the course of their disciplinary area? 2) How do you assess the presence of DCNs in the course curriculum of your subject area? 3) How do you think the DCN guidelines could be considered in the course curriculum of your subject area?

The undergraduate course in Brazil, as well as all higher education, is highly regulated by the State. As the scope of a diploma or diploma is in the national territory the undergraduate courses must train a professional with similar competences, pointed out in the National Curricular Guidelines and implemented in the Curriculum of each Course.

The DCNs, created by LDB 9,394/96 and determined that the Board of Higher Education approve the definition of the duration, duration and duration of courses. The Guidelines should include: A) Profile of the trainee/egress/professsional as the course the pedagogical project should guide the curriculum to the desired professional profile; B) Skills/abilities/attitudes; C) Qualifications and emphases; D) Curricular contents; E) Organization of the course; F) Internships and complementary activities; and G) Monitoring and evaluation.

When analyzing the curriculum of the course of Electrical Engineering students show that although the menus of all disciplines are not available, by the egress profile it is possible to find the skills and abilities presented in DCNs for 
the area of electrical engineering, although in a generalized way. The group draws attention to one point in the Electrical Engineering curriculum, which is the concern of raising awareness about the impact of engineering activities in the social and environmental context. However, they conclude that "it is not a simple task to contemplate with greater efficiency in the curriculum of the course the competences of the DCNs of the area, since the valuation of a humanized formation may not bring immediate benefit to the egress in the search for placement in the labor market" (Participant 23).

The students who analyzed the curriculum of the course of Psychology evidenced the presence of the dispositions of the DCNs in the organization of the course. We can see that there is the existence throughout the undergraduate course of working with the students aspects that correspond to the competences required by the DCNs. They also affirm that "it is possible to identify a strong relationship between competencies and concern, MEC guidelines, with the training of subjects in Psychology who are able to articulate theoretical and practical knowledge, in order to understand the contents learned to apply them in the Stages and then, in practice, in front of the labor market' (Participant 17).

From this exercise it was possible to demonstrate, in a practical and contextualized way, how the course structures in Brazilian higher education are organized, starting from the national legal requirements for the materialization of the same at institutional level according to the professional of each area. This way allows us to look at teaching practice from the point of view of the organization of teaching and, to a certain extent, the management of undergraduate courses, allowing reflection on the course to be taken in classroom practice with a view to training of the course of action.

This analysis refers to the complexity of teacher making and, therefore, reflection on the complexity of the knowledge dynamics present in the educational context from the point of view of teachers in training. In this sense, the evaluation texts of the MES course were analyzed, which illustrate the categories of analysis proposed.

Morin (2008) argues that knowledge has become a social, intellectual and life necessity, in that sense educational systems must take into account the complexity of knowledge taking as a principle that complexity is premised on self-organization that takes into account the Interaction between the peers as an influencer of the environment itself, and the possibility of constructing the new from different perspectives.

In teacher education, emphasizes Guerriero (2017), there are multiple interactions and social processes also influence teacher knowledge, either through network learning or as a result of policy initiatives. In this sense, complexity suggests flexibility, that is, being open to new possibilities that arise along the course of formation.

In the trajectory of the course, we perceive the presence of these prerogatives, which are identified by the analysis of the speeches present in the testimonies of the teachers in formation. These prerogatives take into account the categories of 
analysis: connectivity, co-evolution, emergent order, cascade effect, diversity and redundancy.

The first category, Connectivity, presented as a dimension of the complexity of knowledge, presupposes the interconnectivity and interrelation between multiple agents of the system, and between these agents and their environment.

In the expression of the teachers, the connectivity present in the course, when he affirms that "This discipline is also transversal, being able to integrate fully the various areas of knowledge that are represented through each student" (Participant 2). Teachers also emphasize the importance of contact with the different areas of knowledge, as this contact allowed the broadening of the discussion spectrum and new perspectives on the environment of influence of the area on the environment to which it belongs.

As well as, to affirm to have been this contact foment to the establishment of partnerships, as the Participant 21 reports, "I did not have a contact thus more with other courses from my graduation where I participated in projects of extension of the university. It also gave opportunities to create new bonds and promote partnerships". This also signals the presence of the co-evolutionary perception that considers elements of system change based on interactions.

In this sense, MES 2 reports the presence of the elements of change from the experience in the course. The teacher affirms that participation in the course "opened a vision in me, which allows me today, accept the challenge of being a university professor, different from the traditional model that exists today in higher education, being more open the new teaching methodologies, employ New technologies in pedagogical practices and look at a classroom with the various differences that it can present in cultural, economic, etc. And give an appropriate treatment" (Participant 14).

Just as it is possible to perceive an Emergent Order in the trajectory of the course, since the emergent order implies interactions that result in some kind of global or standard property that could not be predicted by the actions or interactions of any individual agent. That is, from the collective exchanges and experiences one can perceive the intention of establishing a new organization of the teaching profession and the idea of change.

The emerging order can be identified when reported that "I felt impacted by the content of the discipline. Initially, I was conservative, but gradually I am appropriating these teaching-learning perspectives" (Participant 6). As in the experience of the MES teacher 9, when affirming that "the course brought authors/ thinkers who were unfamiliar to me. In addition, in order to understand the multidimensionality of knowledge, it is necessary to understand a certain concept without giving it to others". In this respect, Morin (2008) comments that, as always, with the possibility of revisiting it from new looks.

When interactions are nonlinear, and even small changes in inputs, interactions, or stimuli can cause significant changes throughout the system, this is called cascading effects. This effect can be identified when teachers demonstrate their attitudes towards their practices, "I also hope to bring the experiences ac- 
quired here to my place of work" (Participant 15).

Another teacher reports that "I realized that there are other forms of teaching that can contribute to my area of research and teaching, It was possible to perceive this in the first evaluation referring to the observation of the reference teacher" (Participant 18).

By making these small changes in their practices, teachers can trigger a change in the practice of other teachers and their environment.

Hence the importance of internal Diversity that has as its prerogative, the diversity of elements or agents is an important source of "intelligent" responses to emerging circumstances, presupposes diversity of experiences. That is, the internal diversity enables the individuality of each participant and contemplates the interdisciplinarity proposed in the course. It allows a differentiated trajectory for each one, as evidenced in the reports "although I have participated more as an observer than in a participatory way, I know that new perspectives are opening up in relation to my perception of what it is to teach and to learn" (Participant 22).

The appreciation of internal diversity could also be seen in the statements of Participants 10 and 15, when reporting that "it was interesting to follow the development of the classes, in which we were able to integrate important concepts and theoretical conceptions, worked in Methodology of Higher Education Course, with the practice of tasks performed in class" (10), and "the Methodology of Higher Education Course was developed during the semester, in a very dynamic way. Presentation of seminars, evaluation of the curriculum of the higher courses of which we do parts, evaluation of ENADE tests, workshops involving the participation and creativity of the students" (15).

Throughout the testimonies we perceive the interaction as the guiding thread of the construction of knowledge, be it with its peers or with daily situations in the teaching practice. In this scenario is the category Neighbor interactions, which, in this context, are interpreted as ideas, points of view, etc. that should be able to interact. In a space that allows you to compare, contrast, collide or juxtapose your ideas. This dimension was contemplated in the course by 'being inside' 'the guidelines and curriculum of my course, helped to better understand some issues, both bureaucratic and teaching itself" (Participant 21), as well as participation in "activity of observing a teacher at graduation, helps. To perceive the classroom with other eyes" (Participant 11).

Finally, we have the decentralized Control that aims to enable the interactions with the neighbors, the structure and the results of a collective knowledge producer to be decentralized, that is, in the present context, can be understood as the teacher movement is also a spectator in your classroom. Decentralization was objectified throughout the entire period of the course and we can see that even to a certain extent, it was perceived by teachers and also valued.

In this respect, Participant 20 says, "thank you for living with the teachers during the semester and also the fact that, as mentioned above, they did not 'push' correct answers, but rather put some fleas behind our ears?'. The dynam- 
ics of the classroom presuppose the construction of knowledge and openness to collective reflection and elaboration of new learning, which can be achieved in an effective way when the teacher realizes that he is also apprentice in this process.

The decentralized control was perceived positively, also seeing the cascade effect when analyzing the following testimony: "what also impacted me and made me rethink my practice was the attitude of openness and humility on the part of the two professors of the University. From the very horizontal position of the relation between teacher student in the discipline, I was able to reinforce even more the feeling and the knowledge that the humble openness of the teacher towards the students, facilitates much learning" (Participant 16).

This analysis refers to the materiality of the dimensions in the teachers' perceptions, as well as in the national and institutional policies of teacher education, and these dimensions and their presence are presented in Figure 2.

It is noticed that at national and institutional level the most present dimensions are Emergent order and Internal diversity. We emphasize that these data are intended to illustrate the reality presented in this text, with no generalizations regarding such policies. From a different perspective, we can see from the results of this analysis that the dimension that is most present in the evaluation of teacher-students, and therefore in the course offered, is the dimension of neighbor interactions, followed by Internal diversity and descentralized control. This result helps to corroborate how complex the dynamics of knowledge construction is, since this construction requires constant reflection-action-reflection, which is fostered by the other dimensions. In this sense, we understand that the greater presence of the importance of interaction with peers refers to the immediate, requiring a greater time for these teachers to experience the teaching

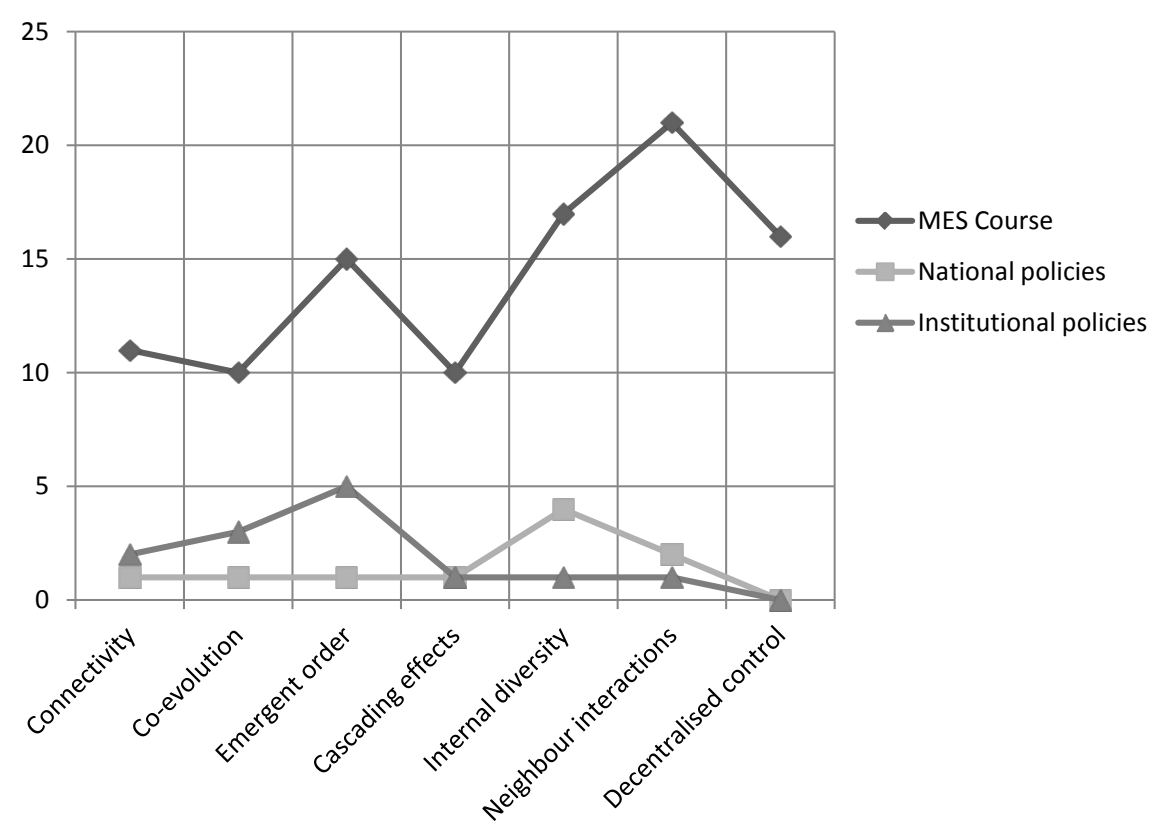

Figure 2. Dimensions of the complexity of the teacher knowledge dynamics. Source: the authors. 
practice and then reflect on the practice performed to revisit their actions and review their practices.

Nevertheless, it was possible to learn (much) from the teachers' speeches about the emergent order for the importance of training during the practice and applicability of the knowledge constructed in the course each week of the semester.

And, even having attended to a group of participants, it was possible to verify that it is possible to have in a same environment, in the same course, different paths to each participant. In the words of one of the teachers "I was able to learn to value student autonomy, teamwork, the importance of group seminars, innovation as new types of exposure using different technologies, and give a new meaning to Students" (Participant 16).

Nevertheless, it was possible to learn (much) from the teachers' speeches about the emergent order for the importance of training during the practice and applicability of the knowledge constructed in the course each week of the semester.

\section{Conclusion}

In this sense, the present article aims to analyze the dynamics of teacher knowledge construction in a university in Brazil. The focus was on national policies and institutional policies for teacher training as well as on the analysis of the materiality of the practice from a teacher training course. The dimensions of the knowledge dynamics proposed by Guerriero (2017) constitute the analytical base.

With regard to the national policies of teacher training, a trend towards centralization of the government has been identified, which coexists with fragile decentralized control. At the same time, it was identified that these dimensions are related to the search for the quality of teaching, much more than just the quality of the teacher. The quality of the teacher does not reflect a look at his practice from reality. This may leave aside the real need of the student. That is, training tends to be more theoretical and, thus, decontextualized.

As far as institutional policies are concerned, there is a tendency for insertion into the dimension of internal diversity, and a movement towards the emergent order dimension, when it allows a change, even if small, in teaching practice.

With respect to the materialization of the educational knowledge in the course of teacher education, we note the dimension of connectivity that, in the trajectories of the research participants, can be perceived the reflection in the dedication to the work and dedication of each participant of the MES-Higher Education Methodology Courses at PUCRS.

Certainly to be possible such a differentiated path, the participation and involvement of the teacher and also the student is crucial for the evolution of the agreement and starting from the skills already developed a priori and those developed throughout the process. Being attentive to the needs of the group is fundamental to a positive outcome and to stimulating new discoveries and con- 
structions.

This reasoning brings to the fore the responsibility of teaching and, above all, the need for training for university teaching that takes into account the assumptions signaled by the inherent complexity of the construction of knowledge. These presuppositions are necessary for the training of teachers/professionals capable of renewing and adapting to new circumstances and the new challenges inherent in the current university context.

\section{References}

Alves, L. (2013). Pedagogia universitária na área da saúde: Perfil docente e proposta de formação em serviço [University Pedagogy in the Health Area: Teaching Profile and Proposal of In-Service Education]. Tese (Doutorado em Educação)-Faculdade de Educação da Universidade Federal de Uberlândia, Uberlândia.

Araújo, A. (2014). Formação pedagógica docente: Movimentos e iniciativas de instituições de ensino superior privadas [Pedagogical Education for Teachers: Movements and Initiatives of Private Higher Education Institutions]. Tese (Doutorado em Educação)—Faculdade de Educação da Universidade Estadual de Londrina-UEL, Londrina.

Aretio, L. G., Corbella, M. R., \& Figaredo, D. D. (2007). De la educación a distancia a la educación virtual [From Distance Education to Virtual Education]. Barcelona: Ariel.

Brasil (1996). Lei No. 9394, de 20 de dezembro de 1996. Estabelece as Diretrizes e Bases Nacionais. Diário Oficial da União. Brasília: Gráfica do Senado, ano CXXXIV, no. 248, 23/12/96, 27833-27841.

Brasil. (2015). Plano Nacional de Educação PNE 2014-2024: Linha de Base [National Plan of Education]. Brasília, DF Inep.

Conte, K. D. M. (2013). Espaço formativo da docência: Um estudo a partir do Programa de Aperfeiçoamento de Ensino (PAE) da Universidade de São Paulo [Teaching Educational Space: A Study Based on the Program for the Improvement of Teaching (PAE) of the University of São Paulo]. Tese (Doutorado em Educação)_Faculdade de Educação da Universidade de São Paulo-USP, São Paulo.

Couto, L. P. (2013). A pedagogia universitária nas propostas inovadoras de universidades brasileiras: Por uma cultura da docência e construção da identidade docente [The University Pedagogy in the Innovative Proposals of Brazilian Universities: For a Culture of Teaching and Construction of the Teaching Identity]. Tese (Doutorado em Educação)—Faculdade de Educação da Universidade de São Paulo-USP, São Paulo.

Debald, B. S. (2014). As trajetórias de desenvolvimento profissional dos docentes nas instituições de ensino superior privado (IESP) do extremo oeste do Paraná [The Professional Trajectories Development of Teachers in Private Higher Education Institutions (IESP) in the Extreme West of Paraná]. Tese (Doutorado em Educação) Faculdade de Educação da Universidade do Vale do Rio dos Sinos-UNISINOS, São Leopoldo.

Eisner, E. W. (2017). The Enlightened Eye: Qualitative Inquiry and the Enhancement of Educational Practice. Teachers College Press.

Gale, T., Mills, C., \& Cross, R. (2017). Socially Inclusive Teaching: Belief, Design, Action as Pedagogic Work. Journal of Teacher Education, 68. https://doi.org/10.1177/0022487116685754

Garcia, B. R. Z. (2012). A contribuição da extensão universitária para a formação docente [The Contribution of University Extension to Teachers Education]. Tese (Doutorado em Educação), São Paulo: Faculdade de Educação da Pontifícia Universidade Católica 
de São Paulo, PUCSP.

Guerriero, S. (Ed.) (2017). Pedagogical Knowledge and the Changing Nature of the Teaching Profession. Paris: OECD Publishing.

Kolb, A. Y., \& Kolb, D. A. (2005). Learning Styles and Learning Spaces: Enhancing Experiential Learning in Higher Education. Academy of Management Learning \& Education, 4, 193-212. https://doi.org/10.5465/AMLE.2005.17268566

Maraschin, M. L. M. (2012). Formação continuada do professor da Educação Superior promovida por ações institucionais [Continuing Education of the Teacher of Higher Education Promoted by Institutional Actions]. Tese (Doutorado em Educação), Porto Alegre: Faculdade de Educação da Universidade Federal do Rio Grande do Sul, UFRGS.

Moraes, R., \& Galiazzi, M. C. (2007). Análise textual discursiva [Discursive Textual Analysis]. Ijuí: Unijuí.

Moreira, D. D. J. G. (2014). Necessidades formativas no campo pedagógico: A perspectiva do desenvolvimento profissional de docentes iniciantes da UEFS [Educational Needs in the Pedagogical Field: The Perspective of the Professional Development of Beginning Teachers of UEFS]. Tese (Doutorado em Educação), Feira de Santana: Faculdade de Educação da Universidade Estadual de Feira de Santana.

Morin, E. (2007). Introdução ao pensamento complexo [Introduction to Complex Thinking](Vol. 3). Porto Alegre: Sulina.

Morin, E. (2008). O método III: O conhecimento do conhecimento [The Method III: The Knowledge of Knowledge]. Porto Alegre: Sulina.

Morin, E. (2014). Ciência com consciência [Science with Consciousness]. Rio de Janeiro: Bertrand.

Nóvoa, A. (Coord.) (1997). Os professores e sua formação [Teachers and Their Education]. Lisboa: Dom Quixote.

Ramos, E. M. O. (2014). Formação pedagógica de professores de uma universidade pública baiana: Teares, linhas e tessituras [Pedagogical Education of Teachers of a Public University in Bahia: Looms, Lines and Tessitures]. Tese (Doutorado em Educação), Feira de Santana: Faculdade de Educação da Universidade Estadual de Feira de Santana.

Santos, M. H. A. D. (2013). Formação continuada de professores da UFPA: Um programa institucional em debate [Continuing Education of UFPA Teachers: An Institutional Program under Discussion]. Tese (Doutorado em Educação), Brasília: Faculdade de Educação da Universidade de Brasília.

Selbach, P. T. D. S. (2015). Desenvolvimento profissional docente em tempos de expansão da educação superior: O movimento nas universidades federais do Rio Grande do Sul [Professional Teacher Development in Times of Expansion of Higher Education: The Movement in the Federal Universities of Rio Grande do Sul]. Tese (Doutorado em Educação), Porto Alegre: Faculdade de Educação da Universidade Federal do Rio Grande do Sul.

Snyder, S. (2013). The Simple, the Complicated, and the Complex: Educational Reform through the lens of Complexity Theory. OECD Education Working Papers, No. 96, OECD Publishing.

Sousa, G. B. D. (2013). Formação continuada de professores do Ensino Superior: Composição organizativa da identidade docente [Continuing Education of Teachers in Higher Education: Organizational Composition of the Teaching Identity]. Tese (Doutorado em Educação), Recife: Faculdade de Educação da de Doutorado da Universidade Federal de Pernambuco. 
Torres, A. R. (2014). A pedagogia universitária e suas relações com as políticas institucionais para a formação de professores de educação superior [University Pedagogy and Its Relations with Institutional Policies for the Education of Higher Education Teachers]. Tese (Doutorado em Educação), São Paulo: Faculdade de Educação da Faculdade de Educação da Universidade de São Paulo, USP.

Vilela, N. S. (2016). Docência universitária: Um estudo sobre a experiência da Universidade Federal de Uberlândia na formação de seus professores [University Teaching: A Study about the Experience of the Federal University of Uberlândia in the Formation of Its Teachers]. Tese (Doutorado em Educação), Uberlândia: Faculdade de Educação da Universidade Federal de Uberlândia.

Zabalza, M. B. (2015). Innovaciones didácticas para la nueva universidad del S. XXI [Didactic Innovations for the New University of S. XXI]. In M. E. A. Engers, M. C. Morosini, \& V. L. Felicetti (Orgs), Educação Superior e Aprendizagem [Higher Education and Learning]. Porto Alegre: EdiPUCRS.

\section{Submit or recommend next manuscript to SCIRP and we will provide best service for you:}

Accepting pre-submission inquiries through Email, Facebook, LinkedIn, Twitter, etc. A wide selection of journals (inclusive of 9 subjects, more than 200 journals) Providing 24-hour high-quality service User-friendly online submission system Fair and swift peer-review system Efficient typesetting and proofreading procedure Display of the result of downloads and visits, as well as the number of cited articles Maximum dissemination of your research work

Submit your manuscript at: http://papersubmission.scirp.org/

Or contact ce@scirp.org 